\title{
Pigment composition, spectral characterization and photosynthetic parameters in Chrysochromulina polylepis
}

\author{
Geir Johnsen ${ }^{1}$, Egil Sakshaug ${ }^{1}$, Maria Vernet ${ }^{2}$ \\ ${ }^{1}$ Trondhjem Biological Station, The Museum, University of Trondheim, Bynesveien 46, N-7018 Trondheim, Norway \\ ${ }^{2}$ Marine Research Division, A-018, Scripps Institution of Oceanography, University of California at San Diego, La Jolla, \\ California 92093, USA
}

\begin{abstract}
The photobiological response of an isolate of the prymnesiophyte Chrysochromulina polylepis, obtained from a bloom in the Skagerrak in May-June 1988, was evaluated with respect to pigment composition, spectral dependence of light harvesting, and photosynthetic parameters of cultures grown at 75 to $120 \mu \mathrm{mol} \mathrm{m} \mathrm{m}^{-2} \mathrm{~s}^{-1}$ irradiance, $16 \mathrm{~h}$ day length and $15^{\circ} \mathrm{C}$. Results were compared to similarly grown cultures of the diatom Skeletonema costatum that appeared before and after the $C$. polylepis bloom. Chl a-specific absorption of light $\left({ }^{\circ} a_{c}\right)$ and chl a-specific absorption of quanta transported to photosystem II, estimated by means of a scaled fluorescence excitation spectrum $\left({ }^{\circ} \mathrm{F}\right)$, were 1.7 to 2.1 times larger in $C$. polylepis than in $S$. costatum in the visible spectrum. C. polylepis harvested blue-green light ( 450 to $500 \mathrm{~nm}$ ) particularly efficiently. This is related to a high proportion of $19^{\prime}$ hexanoyloxyfucoxanthin and chl $c_{3}$ relative to $\mathrm{chl}$ a. Nonetheless, both $C$. polylepis and $S$. costatum absorb light more efficiently in 'clearest' blue ocean water than in 'clearest' green coastal water according to calculations based on spectrally corrected absorbed quanta transported to photosystem II $\left({ }^{\circ} \bar{F}\right)$. Carbon-specific light absorption was about the same in the 2 species since the chl a: $\mathrm{C}$ ratio in $S$. costatum was twice as high as in C. polylepis. C. polylepis had a much smaller maximum carbon uptake $\left(P_{\mathrm{m}}^{\mathrm{B}}\right)$ than $S$. costatum. Differences between the 2 species in terms of photosynthetic parameters, pigment composition, and spectral characteristics normalized to chl $\boldsymbol{a}$, carbon, and cell are discussed.
\end{abstract}

\section{INTRODUCTION}

The bloom of Chrysochromulina polylepis in the Skagerrak in 1988 was first observed after a diatom bloom dominated by Skeletonema costatum along the Swedish coast in the first week of May (Granéli et al. 1989). For the next 2 wk C. polylepis bloomed in the Skagerrak and was transported along the southern coast of Norway. The population of C. polylepis was observed at the pycnocline, often situated at 5 to $10 \mathrm{~m}$ depth. The maximum cell concentrations were 40 to 80

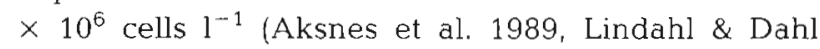
1989). During the bloom period the weather was exceptionally bright and sunny, the waters were extremely stratified, and the temperature in the surface layer was 6 to $12^{\circ} \mathrm{C}$ (Aksnes et al. 1989, Skjoldal \& Dundas 1991). The bloom harmed marine life and aquaculture (Dahl et al. 1989). When the C. polylepis bloom terminated near Arendal (Norway), a bloom of $S$. costatum developed near the surface (Skjoldal \& Dundas 1991).
It has been suggested that prymnesiophyte blooms in the Kattegat/Skagerrak and along the southern coast of Norway occur when limitation by silicate prevents diatoms from forming large stocks (Aksnes et al. 1989, Kaartvedt et al. 1990). The light regime, however, may also play a role, particularly in the initial phase of a bloom before nutrients become limiting. During May, irradiance levels were above the mean values for that month measured in earlier years, and the largest positive anomaly occurred from 6 to 12 May, which coincided with the first registration of Chrysochromulina polylepis (Skjoldal \& Dundas 1991).

Waters in the Skagerrak and along the Norwegian coast differ from oceanic waters in that their colour is blue-green to green, mainly due to high concentrations of humic substances (Jerlov 1976). Spectral irradiance may have an impact on species distribution.

To evaluate the photobiological response of Chrysochromulina polylepis, with respect to light, including its spectral distribution, we investigated pigment compos- 
ition, spectral dependence of light harvesting, and photosynthetic parameters of moderately shadeadapted cultures. These results were then compared to results for Skeletonema costatum, grown in the same light regime and temperature.

\section{MATERIAL AND METHODS}

Culture conditions. The Chrysochromulina polylepis (Manton \& Parke 1962) strain was isolated from a bloom that occurred in May-June 1988 outside Hvaler (outer Oslofjord, Norway: $59^{\circ} 00^{\prime} \mathrm{N}, 10^{\circ} 45^{\prime} \mathrm{E}$ ). C. polylepis was maintained in $\mathrm{f} / 2$ medium (Guillard \& Ryther 1962) at $15^{\circ} \mathrm{C}, 34 \mathrm{ppt}$ salinity and $16 \mathrm{~h}$ day length. Scalar irradiance $\left(E_{0}\right.$, PAR) was 75 or $120 \mu \mathrm{mol} \mathrm{m} \mathrm{m}^{-2} \mathrm{~s}^{-1}$ (provided by 4 Philips TL $40 \mathrm{~W} / 55$ fluorescent tubes), $E_{\mathrm{o}}$ was measured with a QSL-100 quantum sensor (Biospherical Insiruments). Pigment and chemical composition as well as light absorption characteristics did not differ at the 2 irradiances, and we here report the pooled results. Skeletonema costatum, clone Skel-5, isolated from the Trondheimsfjord (Norway) in 1969, was grown at $75 \mu \mathrm{mol} \mathrm{m}^{-2} \mathrm{~s}^{-1}$.

Pigments. For pigment extraction, cultures were concentrated on Whatman GF/C glass fibre filters at $50 \mathrm{mb}$ differential pressure. The filters were then extracted for $20 \mathrm{~h}$ at $4{ }^{\circ} \mathrm{C}$ in darkness in $90 \%$ acetone bubbled with $\mathrm{N}_{2}$ (Chrysochromulina polylepis) or according to Hallegraeff (1981) for Skeletonema costatum. Extracts were cleared by filtration through Whatman GF/C filters and injected into the HPLC column without further treatment. The chlorophyll a (chl a) concentration was also estimated spectrophotometrically according to Jeffrey \&
Humphrey (1975) with the same pretreatment as above. Spectrophotometrical estimation of chl a was used for normalizing the light absorption spectra and chl a:C ratios and were in agreement with the HPLC values.

Pigments were analyzed by high-performance liquid chromatography (Merck \& Hitachi L-6200 HPLC) on a SPHERI-5 RP-18 reverse-phase C-18 column (Brownlee Labs $25 \mathrm{~cm} \times 4.6 \mathrm{~mm}, 5 \mu \mathrm{m}$ particles) by elution in a low-pressure gradient system consisting of a linear gradient from $100 \% \mathrm{~A}$ to $100 \% \mathrm{~B}$ in $10 \mathrm{~min}$ and maintaining B for another $15 \mathrm{~min}$. Solvent A (1 l) consisted of $80: 20$ methanol: water (v:v) where $100 \mathrm{ml}$ of distilled water was prepared with $1.5 \mathrm{~g}$ tetrabutylammonium acetate and $0.96 \mathrm{~g}$ ammonium acetate as ionpairing agent (Mantoura \& Llewellyn 1983). Solvent B consisted of 60:40 methanol:ethyl acetate (v:v). Chlorophylls and carotenoids were monitored by absorption at $440 \mathrm{~nm}$ and quantified by calibration of the column with pigments isolated by thin-layer chromatography from a culture of the diatom Thalassiosira nordenskioeldii. For chlorophylls we used the extinction coefficients of Jeffrey \& Humphrey (1975) and Jeffrey \& Wright (1987). For carotenoids, extinction coefficients were as follows - fucoxanthin and its derivatives: $160 \mathrm{l} \mathrm{g}^{-1} \mathrm{~cm}^{-1}$ at $450 \mathrm{~nm}$; diadinoxanthin, diatoxanthin and their derivatives: $250 \mathrm{l} \mathrm{g}^{-1} \mathrm{~cm}^{-1}$ at maximum absorption (446 to $453 \mathrm{~nm}$ ) (Jeffrey 1968, Davies 1976). Absorption spectra of the eluted pigments were recorded in the eluent on a Hitachi Spectrophotometer Model U-2000 fitted with a flowthrough cell and compared to published spectra for identification (Davies 1976, Wright \& Shearer 1984). A more detailed analysis of the carotenoids of Chrysochromulina polylepis has been published elsewhere

Table 1. Chrysochromulina polylepis. Spectral characteristics and cellular contents of pigments. Parentheses denote shoulders in the absorption spectra

\begin{tabular}{|c|c|c|c|c|}
\hline Pigment & $\begin{array}{c}\text { Reference } \\
\text { time } \\
\text { (min) }\end{array}$ & $\begin{array}{l}\text { Absorption } \\
\text { maxima } \\
\text { (eluent) }\end{array}$ & $\begin{array}{c}\text { Cellular } \\
\text { concentration } \\
\left(p g \text { cell }{ }^{-1}\right)\end{array}$ & $\begin{array}{c}\% \text { Total } \\
\text { carotenoid } \\
(w: w)\end{array}$ \\
\hline Chlorophyll $c_{3}$ & 6.7 & $457,587,625$ & 0.19 & \\
\hline Chlorophyll $\mathrm{C}_{2}^{\mathrm{a}}$ & 7.7 & $447,586,633$ & 0.16 & \\
\hline Fucoxanthin & 9.9 & $450,(468)$ & 0.09 & 13.0 \\
\hline $19^{\prime}$-hexanoyloxyfucoxanthin & 10.3 & $\begin{array}{l}447,470 \\
449^{b}, 473\end{array}$ & 0.45 & 65.2 \\
\hline $9^{\prime}$ cis hexanoyloxyfucoxanthin & 11.0 & 448,468 & 0.03 & 4.3 \\
\hline Diadinoxanthin & 11.4 & $(423), 446,476$ & 0.08 & 11.6 \\
\hline Diatoxanthin & 11.9 & 453,480 & 0.01 & 1.5 \\
\hline $19^{\prime}$-hexanoyloxyparacentrone & & & & \\
\hline 3 -acetate & 12.1 & $(422), 446,471$ & 0.01 & 1.5 \\
\hline Chl a & 14.7 & $433,618,665$ & 0.93 & \\
\hline$\beta$-Carotene & 20.2 & $\begin{array}{l}(428), 454,479 \\
(422)^{c}, 447,472\end{array}$ & 0.02 & 2.9 \\
\hline
\end{tabular}




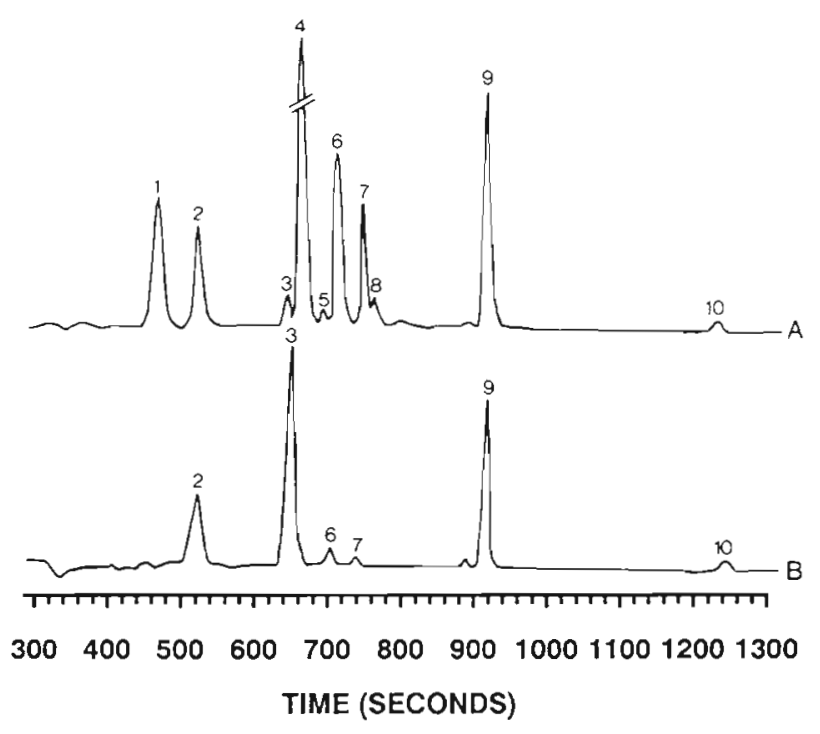

Figure 1. Chromatogram (absorbance at $440 \mathrm{~nm}$ ) of pigment extract obtained from (A) Chrysochromulina polylepis and (B) Skeletonema costatum. Peak identifications: $1=$ chl $c_{3}, 2=$ chl $c_{1+2}, 3=$ fucoxanthin, $4=19$-hexanoyloxyfucoxanthin, $5=9^{\prime}$ cis hexanoyloxyfucoxanthin, $6=$ diadinoxanthin, $7=$ diatoxanthin, $8=19$ hexanoyloxyparacentrone 3 -acetate, $9=$ chl $a, 10=\beta$-carotene

(Bjerkeng et al. 1990). Our system separates chl $c_{3}$ from chl $c_{2}$ well ( 1 min between peaks; Table 1), but chl $c_{2}$ and $c_{1}$ would coelute if the latter were present (Fig. 1).

In vivo spectral characteristics. Chl a-specific light absorption $\left({ }^{\circ} a_{C}\right)$ was measured on Whatman GF/C filters according to Mitchell \& Kiefer (1988). Chl aspecific fluorescence excitation spectra were measured at an emission wavelength of $730 \mathrm{~nm}$ (Neori et al. 1988) and were quantum-corrected by means of the dye Basic Blue 3 (Kopf \& Heinze 1984). They were then scaled by matching of the red peak of the fluorescence excitation spectrum at $676 \mathrm{~nm}$ to the corresponding absorption peak of ${ }^{\circ} a_{c}$ to provide estimates of specific absorption of quanta transported to photosystem II, where $\mathrm{O}_{2}$ is released $\left[{ }^{\circ} \mathrm{F}, \mathrm{m}^{2}(\mathrm{mg} \mathrm{chl} \mathrm{a})^{-1}\right.$; Sakshaug et al. 1991]. ${ }^{\circ} \mathrm{F}$ may be interpreted as an action spectrum for photosynthesis (Haxo 1985, Neori et al. 1988). ${ }^{\circ} a_{c}$ and ${ }^{\circ} \mathrm{F}$ were measured in duplicate at $1 \mathrm{~nm}$ intervals.

The integrated values of ${ }^{\circ} \bar{a}_{c}$ and ${ }^{\circ} \bar{F}$ (400 to $700 \mathrm{~nm}$ ) and thus the photosynthetic efficiency $\left(\alpha^{B}=\phi_{\max }{ }^{\circ} \bar{F}\right.$, where $\phi_{\max }=$ maximum quantum yield) depend on the spectral distribution of ambient light and were calculated according to Morel et al. (1987):

$$
{ }^{\circ} \bar{a}_{\mathrm{c}} \text { or }{ }^{\circ} \bar{F}=\left[\int_{400}^{700} X(\lambda) \cdot E_{0}(\lambda) \mathrm{d} \lambda\right] / E_{0}(\mathrm{PAR})
$$

where ${ }^{\circ} \overline{\mathrm{a}}_{\mathrm{c}}=$ absorbed quanta, spectrally corrected; ${ }^{\circ} \overline{\mathrm{F}}$ $=$ absorbed quanta transported to photosystem II,

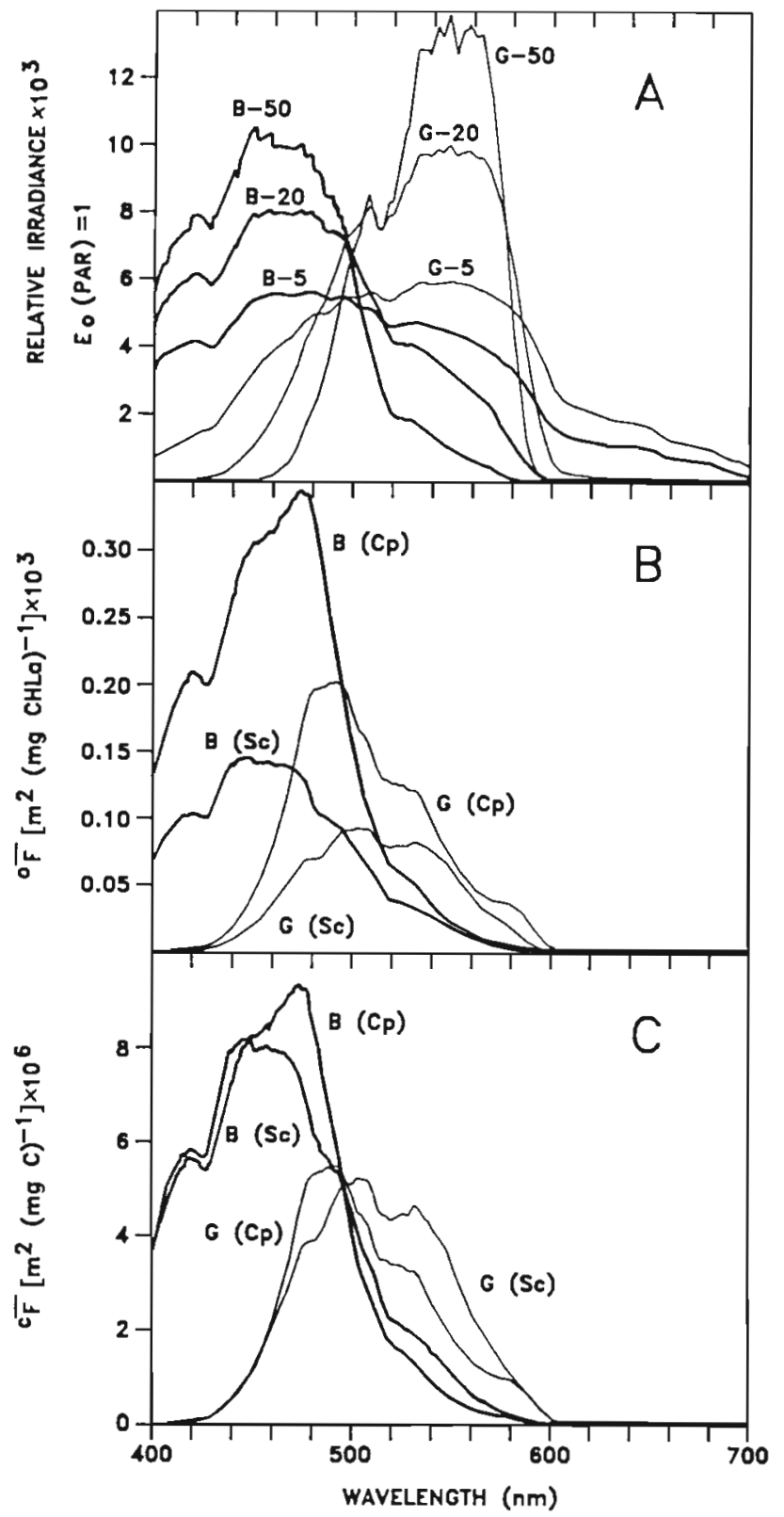

Fig. 2. (A) Relative spectral irradiance $\left[\times 10^{3}, E_{0}(P A R)=1\right]$ at 5,20 and $50 \mathrm{~m}$ depth in 'clearest' green $(\mathrm{G})$ and blue waters (B). (B) Spectrally corrected chl a-normalized absorption of quanta transported to photosystem II ${ }^{\circ} F(\lambda) E_{0}(\lambda), \mathrm{m}^{2}(\mathrm{mg} \mathrm{chl} a)^{-i} \times$ $10^{3}$ ] in 'clearest' green and blue water at $20 \mathrm{~m}$ depth assuming infinitesimal chl a concentration. $E_{\mathrm{o}}(\mathrm{PAR})=1$. (C) $\mathrm{As}(\mathrm{B})$, but carbon-normalized [ $\left.{ }^{C} F(\lambda) E_{\mathrm{o}}(\lambda), \mathrm{m}^{2}(\mathrm{mg} \mathrm{C})^{-1} \times 10^{6}\right]$. Cp: Chrysochromulina polylepis; Sc: Skeletonema costatum

spectrally corrected; $X(\lambda)={ }^{\circ} a_{c}(\lambda)$ or ${ }^{\circ} F(\lambda) ; E_{o}(\lambda)=$ in situ spectral irradiance; $E_{\mathrm{o}}(\mathrm{PAR})=$ integrated irradiance.

Calculations of spectral irradiance vs depth (Fig. 2A) were carried out on the basis of spectral vertical diffuse attenuation coefficients for 'clearest' green water in the

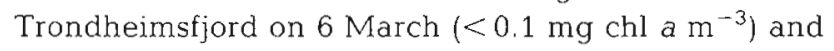


'clearest' blue ocean water (Smith \& Baker 1981) using the daylight spectrum (cloudless sky) in Trondheim $\left(63^{\circ} \mathrm{N}\right)$ at noon on 6 March. Spectral irradiance in 'clearest' green water was measured with a $\mathrm{Li}$-Cor 1800 -UW spectroradiometer $(400$ to $700 \mathrm{~nm})$ at $1 \mathrm{~nm}$ intervals and is very comparable with the colour of Skagerrak water (R. Dalløkken pers. comm.).

Cellular carbon and nitrogen were analyzed in a Carlo Erba Elemental Analyzer, model 1104, after treatment with fuming hydrochlorid acid.

Photosynthetic parameters. $P$ vs $I$ experiments were performed at $15^{\circ} \mathrm{C}$ in 'blue-green' light provided by 4 Philips TLM $115 \mathrm{~W} / 33 \mathrm{RS}$ fluorescent tubes; for spectral characteristics, see Johnsen \& Hegseth (1991). Two prefiltered ampoules with $\mathrm{NaH}^{14} \mathrm{CO}_{3}$ activity of 370 $\mathrm{kBq} \mathrm{ml}^{-1}$ (New England Nuclear, NEC-086S) were added to $80 \mathrm{ml}$ algal culture. Duplicate $1 \mathrm{ml}$ samples were incubated $4 \mathrm{~h}$ into the light phase for $1 \mathrm{~h}$ in $20 \mathrm{ml}$ scintillation vials (Zinsser polyethylene) in a modified 'Photosynthetron' (Lewis \& Smith 1983) with 20 different irradiances ( 7 to $565 \mu \mathrm{mol} \mathrm{m} \mathrm{m}^{-2} \mathrm{~s}^{-1}$; Sakshaug et al. 1991). This technique involves measurement on unfiltered samples and therefore does not discriminate between particulate and dissolved phases of ${ }^{14} \mathrm{C} . P$ vs $I$ parameters were computed according to Platt et al. (1980) by means of the curvilinear least-square regression program LSQUARE (see Table 3 for definitions and units).

\section{RESULTS}

\section{Pigments}

Predominant accessory pigments of Chrysochromulina polylepis are chlorophyll $c_{3}$ (Jeffrey \& Wright 1987 ) and chl $C_{2}$ in addition to $19^{\prime}$-hexanoyloxyfucoxanthin as the major carotenoid, while fucoxanthin contributes $13 \%$ of total carotenoids (Table 1, Fig. 1). In contrast, fucoxanthin is the major accessory pigment in Skeletonema costatum (Pennington et al. 1988; Fig. 1, Table 2). The pigment composition of C. polylepis is similar to that of the Prymnesiophyte Emiliana huxleyi (Wright \& Jeffrey 1987), but differs from the Plymouth isolate of C. polylepis because 2 recently found pigments in our strain (Bjerkeng et al. 1990) are absent in that strain (Riley \& Wilson 1967). Similar to the findings of Riley \& Wilson (1967), our strain exhibits minor amounts of a carotenoid eluted after diatoxanthin (Table 1, Fig. 1 ; at $12.1 \mathrm{~min}$ ) with absorption maxima at 422,446 and $471 \mathrm{~nm}$. This carotenoid was identified as 19'-hexanoyloxyparacentrone 3-acetate (Bjerkeng et al. 1990). Also, a minor carotenoid which is eluted before diadinoxanthin was found (Table 1, Fig. 1; at $11.0 \mathrm{~min}$ ). It has absorption maxima at 448 and $468 \mathrm{~nm}$
Table 2. Cellular contents of pigments in Skeletonema costatum; chl c:chl a and fucoxanthin:chl a ratios in Chrysochromulina polylepis and S. costatum

\begin{tabular}{|c|c|c|}
\hline Pigment & $\begin{array}{l}\text { Cellular conc. } \\
\left(\mathrm{pg} \mathrm{cell}{ }^{-1}\right)\end{array}$ & $\begin{array}{c}\% \text { Total } \\
\text { carotenoid } \\
(w: w)\end{array}$ \\
\hline $\mathrm{Chl} \mathrm{C}_{1+2}$ & 0.23 & \\
\hline Fucoxanthin & 0.43 & 89 \\
\hline Diadinoxanthin & 0.03 & 6.0 \\
\hline Diatoxanthin & 0.01 & 2.4 \\
\hline ChI a & 0.83 & \\
\hline \multirow[t]{2}{*}{$\beta$-Carotene } & 0.01 & 2.6 \\
\hline & C. polylepis & S. costatum \\
\hline Chl $c: \operatorname{chl} a^{a}$ & 0.38 & 0.28 \\
\hline Fucoxanthin : chl a & $0.58^{\mathrm{b}}$ & 0.52 \\
\hline
\end{tabular}

and has been identified as 9' cis hexanoyloxyfucoxanthin (Bjerkeng et al. 1990).

\section{In vivo spectral characteristics}

The in vivo chl a-specific absorption spectrum $\left({ }^{\circ} a_{c}\right)$ of Chrysochromulina polylepis exhibits major peaks at $439,468,592,639$ and $675 \mathrm{~nm}$, which correspond to chl a $(439,639$ and $675 \mathrm{~nm})$ and chl $c_{2}+c_{3}(468,592$, and in part $639 \mathrm{~nm}$; Fig. 3A). A shoulder at 500 to 540 $\mathrm{nm}$ probably corresponds to in vivo absorption by the carotenoids 19'-hexanoyloxyfucoxanthin and fucoxanthin, which may also contribute significantly at $468 \mathrm{~nm}$

The scaled fluorescence excitation spectrum ${ }^{\circ} \mathrm{F}$ of Chrysochromulina polylepis exhibits a maximum at $472 \mathrm{~nm}$, which corresponds to light-energy transport from 19'-hexanoyloxyfucoxanthin, chl $C_{2}$ and in particular chl $c_{3}$, which have maximum absorption at $457 \mathrm{~nm}$ in solution (Table 1, Fig. 3B).

On a chl a-normalized basis, Chrysochromulina polylepis absorbs light far more efficiently than Skeletonema costatum: ${ }^{\circ} a_{c}(676 \mathrm{~nm})$ is $0.019 \mathrm{~m}^{2}(\mathrm{mg} \mathrm{chl} a)^{-1}$ in the former vs 0.013 in the latter (Fig. 3A). Corresponding values for $440 \mathrm{~nm}$ are 0.044 and $0.020 \mathrm{~m}^{2}\left(\mathrm{mg} \mathrm{chl} \mathrm{a}^{-1}\right.$ (Fig. 3A)

\section{Photosynthetic parameters}

Chrysochromulina polylepis exhibits a maximum photosynthetic rate $\left(P_{\mathrm{m}}^{\mathrm{B}}\right)$ of $1.3 \mathrm{mg} \mathrm{C}(\mathrm{mg} \mathrm{chl} \mathrm{a})^{-1} \mathrm{~h}^{-1}$. This rate compares well to in situ assimilation num- 


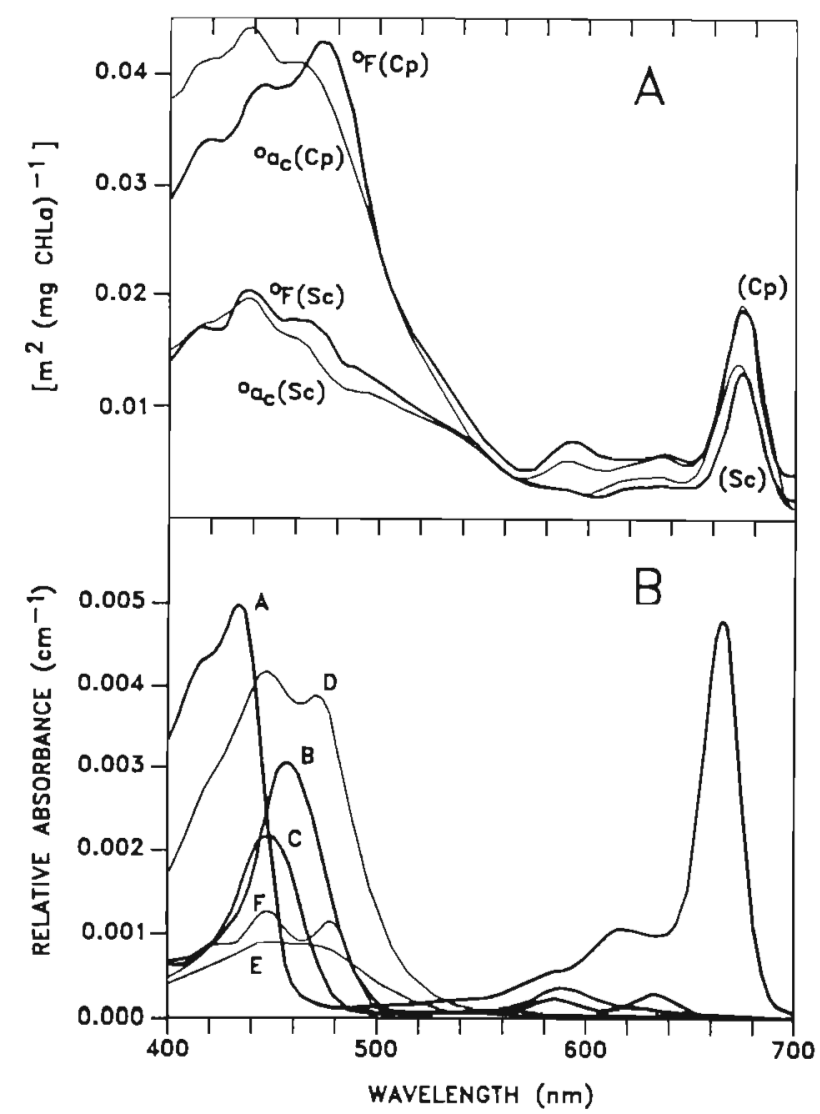

Fig. 3. Chrysochromulina polylepis $(\mathrm{Cp})$ and Skeletonema costatum (Sc). (A) Chl a-specific absorption $\left({ }^{\circ} a_{C}\right.$ ) and scaled fluorescence excitation spectra $\left({ }^{\circ} F\right.$. (B) In vitro absorbance of the individual pigments isolated from $C$. polylepis and scaled to the cellular concentration presented in Table 1: (A) Chl $a_{i}(B)$ chl $c_{3}$, (C) chl $c_{2}$, (D) 19 '-hexanoyloxyfucoxanthin, (E) fucoxanthin, (F) diadinoxanthin (solvent; eluent from the HPLC column)

bers $\left(P^{B}\right)$ of 0.3 to $1.9 \mathrm{mg} C(\mathrm{mg} \mathrm{chl} \mathrm{a})^{-1} \mathrm{~h}^{-1}$ for $\mathrm{C}$. polylepis at the pycnocline in the southern Skagerrak on 30 May to 1 June 1988 (Nielsen et al. 1990). $P_{\mathrm{m}}^{\mathrm{B}}$ for Skeletonema costatum, however, is much higher $[4.7$ mg $C(m g \text { chl a })^{-1} h^{-1} ; \mathrm{M}$. Gilstad \& G. Johnsen unpubl.]. Photosynthetic efficiency $\left(\alpha^{B}\right)$ and the photoadaptation index $\left(I_{k}\right)$ for $C$. polylepis in incubator illumination was $0.027 \mathrm{mg} C(\mathrm{mg} \mathrm{chl} \mathrm{a})^{-1} \mathrm{~h}^{-1}$ ( $\mu \mathrm{mol}$ $\mathrm{m}^{-2} \mathrm{~s}^{-1}$ ) and $48 \mu \mathrm{mol} \mathrm{m}^{-2} \mathrm{~s}^{-1}$, respectively. The $a^{B}$ value in $S$. costatum was almost the same as that for $C$. polylepis [0.023 $\left.\mathrm{mg} \mathrm{C}(\mathrm{mg} \mathrm{chl} \mathrm{a})^{-1} \mathrm{~h}^{-1}\left(\mu \mathrm{mol} \mathrm{m}{ }^{-2} \mathrm{~s}^{-1}\right)\right]$, while $I_{k}$ was 4.4 times higher in the former $(211 \mu \mathrm{mol}$ $\left.\mathrm{m}^{-2} \mathrm{~s}^{-1}\right)$. In C. polylepis, the photoinhibition index $\left(\beta^{\mathrm{B}}\right)$ and the photoinhibition irradiance $\left(l_{b}\right)$ were $0.9 \times 10^{-3}$ $\mathrm{mg} \mathrm{C}(\mathrm{mg} \mathrm{chl} \mathrm{a})^{-1} \mathrm{~h}^{-1}$ ( $\left.\mathrm{mmol} \mathrm{m} \mathrm{m}^{-2} \mathrm{~s}^{-1}\right)$, and $1700 \mu \mathrm{mol}$ $\mathrm{m}^{-2} \mathrm{~s}^{-1}$, respectively (Table 3 ). Thus, in contrast to $S$. costatum, no photoinhibition of photosynthesis was registered (Table 3 ).

\section{DISCUSSION}

\section{Pigments}

A comparison with other bloom-forming prymnesiophytes from western Europe demonstrates that Chrysochromulina polylepis is similar to Emiliana huxleyi, Phaeocystis pouchetii and Prymnesium parvum in having chl $c_{3}$ as well as chl $c_{2}$ (Jeffrey \& Wright 1987, Fawley 1989), and to E. huxleyi and Corymbellus aureus (Gieskes \& Kraay 1986) in the dominance of 19'. hexanoyloxyfucoxanthin. It differs, however, from $E$. huxleyi by not having a phytol-containing chl $c$ derivative (Nelson \& Wakeham 1989).

As expected for shade-adapted Chrysochromulina polylepis, the photosynthetically active pigments (chl $a$, $c_{2}$, and $c_{3}, 19^{\prime}$-hexanoyloxyfucoxanthin and fucoxanthin) are abundant while carotenoids believed to be involved in photoprotection (diadinoxanthin and diatoxanthin; Haxo 1985, Vernet et al. 1989) are low with $13 \%$ by weight of the total carotenoid in the cell (Table 1). Diadino- and diatoxanthin contributed $8 \%$ of total carotenoids in shade-adapted Skeletonema costatum, and 2.5 to $15 \%$ in shade-adapted Barents Sea diatoms (Sakshaug et al. 1991, G. Johnsen unpubl.; Table 2 , Fig. 1)

We found a chl a content of $0.93 \mathrm{pg} \mathrm{cell}^{-1}$ in Chrysochromulina polylepis. This indicates that our experiments are representative of cells living at the pycnocline. This chl a content belongs to the high range of data for the Skagerrak bloom in May/June 1988 (0.15 to $1.0 \mathrm{pg}$ cell $^{-1}$; Dahl et al. 1989, Lindahl \& Dahl 1989, Nielsen et al. 1990). The chl a content in Skeletonema costatum is comparable to that of C. polylepis, i.e. 0.83 $\mathrm{pg} \mathrm{cell} \mathrm{l}^{-1}$. This value is comparable to the chl a content $\left(0.85 \mathrm{pg} \mathrm{cell}{ }^{-1}\right)$ according to earlier studies of the same clone of $S$. costatum grown at $70 \mu \mathrm{mol} \mathrm{m} \mathrm{m}^{-2} \mathrm{~s}^{-1}, 15^{\circ} \mathrm{C}$, and 10 h daylength (Sakshaug \& Andresen 1986).

\section{In vivo spectral characteristics}

The fluorescence maximum at $472 \mathrm{~nm}$ (Fig. 3A) is not evident in ${ }^{\circ} a_{c}$ and may represent a particularly efficient transfer of light-energy from 19'-hexanoyloxyfucoxanthin, chl $c_{2}$ and chl $c_{3}$ to reaction-center chl a in photosystem II. Other fluorescence excitation peaks coincide with the absorption peaks. Comparison of the spectral characteristics of the isolated pigments with ${ }^{\circ} \mathrm{F}$ indicate that almost all of the measured chloroplast pigments of Chrysochromulina polylepis transfer light-energy to photosystem II. This is in agreement with Haxo's survey of photosynthetic effectiveness in the similar pigmented Emiliania huxleyi, based on spectral absorption, fluorescence excitation and $\mathrm{O}_{2}$-action spectrum (Haxo 1985). 
Table 3. Chrysochromulina polylepis and Skeletonema costatum. Photosynthetic parameters in 'blue-green' incubator light and cell chemistry (data for S. costatum: M. Gilstad \& G. Johnsen unpubl.). Photosynthetic parameters: $p_{\mathrm{m}}^{\mathrm{B}}$ realized maximum uptake; $P_{s}^{\mathrm{B}}$, theoretical maximum uptake; $\alpha^{\mathrm{B}}$, photosynthetic efficiency; $\beta^{\mathrm{B}}$, photoinhibition index $I_{k}\left(=p_{\mathrm{m}}^{\mathrm{B}} / \alpha^{\mathrm{B}}\right)$, photoadaptation index; $I_{\mathrm{m}}$ optimum irradiance; $I_{b}$, photoinhibition irradiance. ${ }^{\circ} \bar{a}_{c}$ : spectrally corrected absorbed quanta; ${ }^{\circ} \bar{F}$. absorbed quanta transported to photosystem II (see Eq. 1). Superscript ${ }^{C}$ denotes carbon-normalized coefficients

\begin{tabular}{|c|c|c|c|}
\hline Parameter & C. polylepis & S. costatum & Unit \\
\hline$p_{\mathrm{s}}^{\mathrm{B}}$ & 1.5 & - & $\operatorname{mgC}(\mathrm{mg} \mathrm{chl} a)^{-1} \mathrm{~h}^{-1}$ \\
\hline$P_{\mathrm{m}}^{B}$ & 1.3 & 4.7 & $\operatorname{mgC}(\mathrm{mg} \mathrm{chl} a)^{-1} \mathrm{~h}^{-1}$ \\
\hline$\alpha^{\mathrm{B}}$ & 0.027 & 0.023 & $\mathrm{mgC}(\mathrm{mg} \mathrm{chl} \mathrm{a})^{-1} \mathrm{~h}^{-1}\left(\mu \mathrm{mol} \mathrm{m} \mathrm{m}^{-2} \mathrm{~s}^{-1}\right)^{-1}$ \\
\hline$\beta^{\mathrm{B}} \times 10^{3}$ & 0.90 & 0 & $\operatorname{mg} C(\mathrm{mg} \mathrm{chl} \mathrm{a})^{-1} \mathrm{~h}^{-1}\left(\mu \mathrm{mol} \mathrm{m} \mathrm{m}^{-2} \mathrm{~s}^{-1}\right)^{-1}$ \\
\hline$I_{k}$ & 48 & 211 & $\mu \mathrm{mol} \mathrm{m} \mathrm{m}^{-2} \mathrm{~s}^{-1}$ \\
\hline$l_{m}$ & 191 & - & $\mu \mathrm{mol} \mathrm{m}-2 \mathrm{~s}^{-1}$ \\
\hline$I_{\mathrm{b}}$ & 1700 & - & $\mu \mathrm{mol} \mathrm{m}^{-2} \mathrm{~s}^{-1}$ \\
\hline$\circ \bar{a}_{\mathrm{Cl}}{ }^{\circ} \overline{\mathrm{F}}$ & 0.012 & 0.0071 & $\mathrm{~m}^{2}(\mathrm{mg} \mathrm{chl} \mathrm{a})^{-1}$ \\
\hline Chl a:C & 0.027 & 0.056 & $w: w$ \\
\hline$N: C$ & 0.12 & 0.17 & at. at. \\
\hline$c_{\bar{a}}, c_{\bar{F}}$ & 0.32 & 0.40 & $\mathrm{~m}^{2}(\mathrm{mg} \mathrm{C})^{-1}$ \\
\hline${ }^{\mathrm{C}} P_{\mathrm{s}}$ & 0.041 & - & $h^{-1}$ \\
\hline${ }^{\mathrm{c}} p_{\mathrm{m}}$ & 0.035 & 0.26 & $h^{-1}$ \\
\hline$c_{\alpha}$ & 0.00073 & 0.0013 & 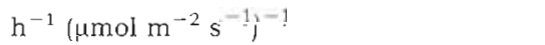 \\
\hline
\end{tabular}

${ }^{\circ} a_{c}$ and ${ }^{\circ} \mathrm{F}$ differ relatively little whether Chrysochromulina polylepis or Skeletonema costatum are concerned - presumably as a result of the small content of photoprotective pigments, namely diadino- and diatoxanthin, in shade-adapted cells (Vernet et al. 1989, Sakshaug et al. 1991). While ${ }^{\circ} \mathrm{F}$ of $C$. polylepis exhibits a maximum at $472 \mathrm{~nm}$, ${ }^{\circ} \mathrm{F}$ of $S$. costatum exhibits a maximum at $440 \mathrm{~nm}$. Thus $C$. polylepis is somewhat more specialized than $S$. costatum in absorption of blue-green light (Figs. 2B, C \& 3A).

\section{Light harvesting}

Based on chl a-normalization, Chrysochromulina polylepis absorbs blue-green incubator light 1.7 times more efficiently than Skeletonema costatum, whether in terms of ${ }^{\circ} \vec{F}$ or ${ }^{\circ} \bar{a}_{c}$ (Table 3 ). This is related to the large amounts of $19^{\prime}$-hexanoyloxyfucoxanthin, chl $c_{2}$ and chl $c_{3}$ relative to chl a (Fig. 3 ). Since the fucoxanthin: chl a ratio in both species (fucoxanthin $+19^{\prime}$-hexanoyloxyfucoxanthin in C.polylepis) is about 0.5, the large difference in chl a-normalized spectra between species must be due to particularly efficient light-harvesting pigment-protein bonds in C. polylepis. The shoulder at $592 \mathrm{~nm}$ in both ${ }^{\circ} a_{\mathrm{c}}$ and ${ }^{\circ} \mathrm{F}$ obtained from $C$. polylepis indicates that chl $C_{2}+3$ are efficient light-harvesting pigments (Figs. 2B, C \& 3). C. polylepis is more efficient than $S$. costatum not only because these pigments transfer light-energy to photosystem II extremely efficiently, but also because it has 1.36 times more of total chl $c$ per unit chl a (Fig. 3A, Table 2). C. polylepis, however, has an $\alpha^{B}$ value in blue-green incubation light which is only 1.2 times higher than in S. costatum.

The 1.4 times higher value of Chrysochromulina polylepis relative to Skeletonema costatum for ${ }^{\circ} a_{c}$ at $676 \mathrm{~nm}$, in which absorption by accessory pigments is negligible, indicates that the 'packaging' effect, i.e. self-shading in and between chloroplasts (Kirk 1983), is important in $S$. costatum. This is presumably related to the twice as high chl a: C ratio in $S$. costatum relative to C. polylepis (Table 3 ). The 2.2 times higher value for ${ }^{\circ} a_{c}$ $(440 \mathrm{~nm})$ in $C$. polylepis compared to $S$. costatum reflects that accessory pigments are more important in live cells of $C$. polylepis than in live cells of $S$. costatum (Fig. 3A).

\section{Light harvesting vs spectral irradiance}

To demonstrate the effect of spectral distribution on algal photosynthesis in low light, we calculated ${ }^{\circ} \bar{F}$, the absorbed quanta transported to photosystem II (Eq. 1), of Chrysochromulina polylepis and Skeletonema costatum in green and blue waters, assuming infinitesimal chl a concentrations (Table 4). It turns out that both species, in spite of being coastal strains, absorb light more efficiently in blue than in green water (Fig. 2B, C). Per unit chl $a, C$. polylepis absorbs quanta transported to photosystem II $\left({ }^{\circ} \bar{F}\right) 1.96,1.86$ and 1.71 times more efficiently than $S$. costatum in green coastal water at 5,20 and $50 \mathrm{~m}$ depth, respectively, and 2.07 to 2.13 times more efficiently than $S$. costatum in blue water (Table 4, Fig. 2B). $\alpha^{B}$ corresponds to the product of $\phi_{\max }$, 
Table 4. Chrysochromulina polylepis $(C P)$ and Skeletonema costatum (Sc). Spectrally corrected transport of absorbed quanta to photosystem II (Eq. 1), based on data from Fig. $2 ;{ }^{\circ} \bar{F}$ $\left[\mathrm{m}^{2}(\mathrm{mg} \mathrm{chl} \mathrm{a})^{-1}\right],{ }^{c} \bar{F}\left[\mathrm{~m}^{2}(\mathrm{mg} \mathrm{C})^{-1} \times 10^{3}\right]$ in green coastal waters $(G)$ and blue oceanic waters (B; from Smith \& Baker 1981) at 5, 20 and $50 \mathrm{~m}$ depth, assuming infinitesimal $\mathrm{chl} \mathrm{a}$ concentration

\begin{tabular}{|c|c|c|c|c|c|c|}
\hline $\begin{array}{l}\text { Water, } \\
\text { depth }\end{array}$ & $\begin{array}{c}{ }^{\circ} \bar{F} \\
(C p)\end{array}$ & $\begin{array}{c}o \bar{F} \\
(S C)\end{array}$ & $\frac{{ }^{\circ} \bar{F}(C p)}{{ }^{\circ} \bar{F}(S C)}$ & $\begin{array}{c}c \bar{F} \\
(C p)\end{array}$ & $\begin{array}{l}c_{\bar{F}} \\
(S c)\end{array}$ & $\frac{{ }^{c} \bar{F}(C p)}{{ }^{c} \bar{F}(S c)}$ \\
\hline $\mathrm{G}, 5 \mathrm{~m}$ & 0.018 & 0.0092 & 1.96 & 0.49 & 0.52 & 0.94 \\
\hline $\mathrm{G}, 20 \mathrm{~m}$ & 0.016 & 0.0086 & 1.86 & 0.43 & 0.48 & 0.90 \\
\hline $\mathrm{G}, 50 \mathrm{~m}$ & 0.013 & 0.0076 & 1.71 & 0.35 & 0.43 & 0.81 \\
\hline B, $5 \mathrm{~m}$ & 0.023 & 0.011 & 2.09 & 0.62 & 0.62 & 1.00 \\
\hline $\mathrm{B}, 20 \mathrm{~m}$ & 0.029 & 0.014 & 2.07 & 0.79 & 0.79 & 1.00 \\
\hline $\mathrm{B}, 50 \mathrm{~m}$ & 0.034 & 0.016 & 2.13 & 0.92 & 0.90 & 1.02 \\
\hline
\end{tabular}

which can be considered as constant in shade-adaptated cells (Langdon 1988), and the spectrally corrected transport of light-energy to photosystem II $\left({ }^{\circ} \bar{F}\right)$. As a consequence, $\alpha^{B}$ should vary in a linear proportion with ${ }^{\circ} \bar{F}$ (Table 4 ; Johnsen \& Hegseth 1991). Per unit carbon, however, absorption of light $\left({ }^{C} \bar{F}\right.$ and $\left.C_{\bar{a}_{c}}\right)$ by $C$. polylepis is actually a little smaller than in $\mathrm{S}$. costatum in green water while being equal in blue water (Table 4 , Fig. 2C). Because growth is related to carbon-normalized parameters, a high value of the chlorophyllnormalized factor ${ }^{\circ} \bar{F}$ can be deceptive in the context of growth rate; i.e. the high ${ }^{\circ} \bar{F}$ of $C$. polylepis is offset by the high chl a: C ratio in $S$. costatum. One should bear in mind, however, that to compare with $S$. costatum is to compare with the most successful diatom species in nearshore Norwegian coastal waters and fjords (see Sakshaug \& Andresen 1986). In fact, one may conclude that both species are efficient in absorption of blue as well as blue-green light (see Table 4).

\section{Photosynthetic parameters}

The photosynthetic parameters in Chrysochromulina polylepis indicate relatively high susceptibility to photoinhibition compared to shade-adapted diatoms (Richardson et al. 1983). High susceptibility to strong light, however, was not observed in field samples (Nielsen et al. 1990). They observed assimilation numbers from 0.6 to $6.7 \mathrm{mg} C$ (mg chl a) ${ }^{-1} \mathrm{~h}^{-1}$ for $C$. polylepis obtained from the pycnocline and illuminated at an irradiance corresponding to $2.5 \mathrm{~m}$ depth. Such differences in assimilation numbers are likely to be due to difference in incubation technique, temperature, photoadaptation (Sakshaug et al. 1991), or different isolates may be inherently different physiologically.

While shade-adapted Chrysochromulina polylepis has a low $P_{\mathrm{m}}^{\mathrm{B}}$ and $I_{k}$ well below the growth irradiance used in our experiments, in addition to an extremely low value for carbon-normalized maximum carbon uptake ( ${ }^{C} P_{m}$; Table 3$)$, the opposite is true for shadeadapted $S$. costatum. This, and the high susceptibility of C. polylepis to photoinhibition, may imply that shade-adapted C. polylepis, in contrast to Skeletonema costatum, cannot tolerate short periods of strong light well. It may, however, compensate for this by phototaxis. Phototactic compensation is only possible in wellstratified water layers, such as during the bloom of $C$. polylepis in Kattegat/Skagerrak in 1988. Consequently, the 2 species, when shade-adapted, may differ primarily in their response to strong light.

Although not measured here, the growth rate of Chrysochromulina polylepis should be low. Our set of photosynthetic coefficients implies a gross growth rate (net rate, $\mu+$ respiration rate, $r$ ) of $0.46 \mathrm{~d}^{-1}$ at $75 \mu \mathrm{mol}$ $\mathrm{m}^{-2} \mathrm{~s}^{-1}$ and 16 h day length, in contrast to $1.26 \mathrm{~d}^{-1}$ for Skeletonema costatum according to studies by Sakshaug et al. (1989). Correspondingly, the net growth rate $(\mu)$ of $C$. polylepis should be half or less than the value of about $0.8 \mathrm{~d}^{-1}$ for $S$. costatum, unless the species differ profoundly in terms of the respiration rate (Sakshaug \& Andresen 1986).

\section{CONCLUSIONS}

The high efficiency of Chrysochromulina polylepis with respect to light harvesting in blue-green to green waters (Table 4) may have played a role in its success during the initial phase of the bloom in the Kattegat/ Skagerrak in summer 1988. Moreover, low surface salinity, high surface temperature and the resulting stratification of the upper layers, as well as unusually sunny weather, may presumably have ensured close to ideal conditions for this species (Aksnes et al. 1989, Skjoldal \& Dundas 1991). Similar conditions have also favoured another Chrysochromulina bloom, i.e. of the toxic Chrysochromulina leadbeateri mixed with $C$. ericina, $C$. hirta and peridinin-containing dinoflagellates in the surface layers in the Vestfjord/Tysfjord area in northern Norway in May-June 1991 (Johnsen 1991).

Our calculations indicate that Skeletonema costatum would grow faster than Chrysochromulina polylepis, particularly in the medium-to-low light near the pycnocline, considering the different carbon-specific photosynthetic efficiencies ( ${ }^{c} a^{\prime}$ ) of the 2 species (Table 3 ). Because a majority of 'nuisance' species appear to grow slower than many diatoms in comparable light regimes (Brand \& Guillard 1981), one might justifiably ask why $S$. costatum and other fast-growing species are absent during some phytoplankton blooms, rather than why C. polylepis and related species are successes. 
This question, however, cannot be answered in terms of light strategies alone. Initial stocks of competitive species, for instance, may have been too small or absent, and a low supply of silicate may have controlled the diatom stock, at least late in the bloom of $C$. polylepis (Aksnes et al. 1989, Skjoldal \& Dundas 1991). Moreover, whereas diatoms such as Skeletonema are bound to sink and to be grazed to a considerable extent, $C$. polylepis may stay near the pycnocline due to its motility while not being grazed appreciably due to its toxicity (Nielsen et al. 1990).

Acknowledgements. This work was supported by The Royal Norwegian Council for Scientific and Industrial Research (G.J.) and The Norwegian Research Council for Science and the Humanities (M.V.). Thanks are due to M. V Nielsen and L. Granskog for growing C. polylepis, M. Gilstad for use of unpublished data, and Kjersti Andresen for drawing the figures. We also thank Prof. E. Paasche and S. Myklestad for supplying isolates of $C$. polylepis and $S$. costatum, respectively. Contribution 251, Trondhjem Biological Station.

\section{LITERATURE CITED}

Aksnes, D. I., Aure, J., Furnes, G. K., Skjoldal, H. R., Sætre, R. (1989). Analyse av Chrysochromulina polylepis - oppblomstringen i Skagerrak, mai 1988. Miljøbetingelser og mulige årsaker In: Draget, H. B. D., Holthe, T (eds.) Oppblomstring av Chrysochromulina polylepis 1988, Report 12. Directorate for Nature Management Norway, p. $17-20$ (in Norwegian)

Bjerkeng, B., Vernet, M., Nielsen, M.V., Liaaen-Jensen, S. (1990). Carotenoids of Chrysochromulina polylepis (Prymnesiophyceae). Biochem. Syst. Ecol. 18: 303-306

Brand, L. E., Guillard, R. R. L. (1981). The effects of continuous light and light intensity on the reproduction rates of twenty-two species of marine phytoplankton. J. exp. mar. Biol. Ecol. 50: 119-132

Dahl, E., Lindahl, O., Paasche, E., Throndsen., J. (1989). The Chrysochromulina polylepis bloom in Scandinavian waters during spring 1988. In: Cosper, E. M., Bricelj, V. M., Carpenter, E. J. (eds.) Novel phytoplankton blooms. Coastal and Estuarine Studies 35. Springer Verlag, Heidelberg, p. 383-485

Davies, B. H. (1976). Carotenolds In: Goodwin, T W (ed.) Chemistry and biochemistry of plant pigments. Academic Press, New York, p. 38-155

Fawley, M. W. (1989). Detection of chlorophylls $c_{1}, c_{2}$ and $c_{3}$ in pigment extracts of Prymnesium parvum (Prymnesiophyceae). J. Phycol. 25: 601-604

Gieskes, W. W. C., Kraay, G. W (1986). Analysis of phytoplankton pigments by HPLC before, during and after mass occurrence of the microflagellate Corymbellus aureus during the spring bloom in the open North Sea in 1983. Mar. Biol. 92: $45-52$

Granéli, E., Carlsson, P., Olsson, P., Sundström, B., Granéli, W. Lindahl, O. (1989). From anoxia to fish poisoning: the last ten years of phytoplankton blooms in Swedish marine waters. In: Cosper, E. M., Bricelj, V M., Carpenter, E. J. (eds.) Novel phytoplankton blooms. Coastal and Estuarine Studies 35. Springer Verlag, Heidelberg, p. $407-427$

Guillard, R. R. L., Ryther, J. H. (1962). Studies of marine plankton diatoms. I. Cyclotella nana Hustedt, and Detonula confervacea (Cleve) Gran. Can. J. Microbiol. 8: $229-239$

Hallegraeff, G. M. (1981). Seasonal study of phytoplankton pigments and species at a coastal station off Sydney: importance of diatoms and the nanoplankton. Mar Biol. 61: $107-118$

Haxo, F. T (1985). Photosynthetic action spectrum of the coccolithphorid, Emiliania huxleyi (Haptophyceae): $19{ }^{\circ}$ hexanoyloxyfucoxanthin as antenna pigment. J. Phycol. $21 \quad 282-287$

Jeffrey, S. W (1968). Quantitative thin-layer chromatography of chlorophylls and carotenoids from marine algae. Biochim. Biophys. Acta. 162: 271-285

Jeffrey, S. W., Humphrey, G. F. (1975). New spectrophotometric equations for determining chlorophylls $a, b, c_{1}$ and $c_{2}$ in higher plants, algae and natural phytoplankton. Biochem. Physiol. Pflanz. 167: 191-194

Jeffrey, S. W., Wright, S. W (1987). A new spectrally distinct component in preparations of chlorophyll $c$ from the microalga Emiliania huxleyi (Prymnesiophyceae). Biochim. Biophys. Acta 894: 180-184

Jerlov, N. G. (1976). Marine optics, 2nd edn. Flsevier, Amsterdam

Johnsen, G. (1991). Identification of Chrysochromulina leadbeateri by means of remote sensing. Fisken og Havet. 3: 73-84 (in Norwegian with English summary)

Johnsen, G., Hegseth, E. N. (1991). Photoadaptation of sea-ice microalgae in the Barents Sea. Polar Biol. 11 179-184

Kaartvedt, S., Johnsen, T. M., Aksnes, D. L., Lie, U., Svendsen, H. (1990). Giftalgen Prymnesium parvum i Ryfylkefjordene, juli-august 1989. IMB Rapport 2: University of Bergen, Norway, p. 1-68 (in Norwegian)

Kirk, J. T O. (1983). Light and photosynthesis in aquatic ecosystems. Cambridge University Press, Cambridge

Kopf, U., Heinze, J. (1984). 2,7-bis(diethylamino)phenazoxonium chloride as a quantum counter for emission measurements between 240 and $700 \mathrm{~nm}$. Analyt. Chem. 56: 1931-1935

Langdon, C. (1988). On the causes of interspecific differences in the growth-jrradiance relationship for phytoplankton. II. A general review. J. Plankton Res. 10: 1291-3112

Lewis, M. R., Smith, J. C. (1983). A small volume, shortincubation time method for measurement of photosynthesis as a function of incident irradiance. Mar. Ecol. Prog. Ser. 13: 99-102

Lindahl, O., Dahl, E. (1989). On the development of the Chrysochromulina polylepis bloom in the Skagerrak in MayJune 1988. In: Granéli, E., Sundström, B., Edler, L., Anderson, D. M. (eds.) Toxic marine phytoplankton. Elsevier, Amsterdam, p. 189-194

Manton, J., Parke, M. (1962). Preliminary observations on scales and their mode of origin in Chrysochromulina polylepis sp. nov. J. mar. biol. Ass. U.K. 42: 565-578

Mantoura, R. F. C., Llewellyn, C. A. (1983). The rapid determunation of algal chlorophyll and carotenoid pigments and their breakdown products in natural waters by reversephase high-pressure liquid chromatography. Analyt. Chim. Acta 151 297-314

Mitchell, B. G., Kiefer, D. A. (1988]. Chlorophyll a specificabsorption and fluorescence excitation spectra for lightlimited phytoplankton. Deep Sea Res. 35: 639-663

Morel, A., Lazzara, L., Gostan, J. (1987). Growth rate and quantum yield time response for a diatom to changing irradiance (energy and color). Limnol. Oceanogr. 32: 1066-1084

Nelson, J. R., Wakeham, S G. (1989). A phytol-substituted 
chlorophyll c from Emiliana huxleyi (Prymnesiophyceae). J. Phycol. 25: 761-766

Neori, A., Vernet, M., Holm-Hansen, O., Haxo, F. T (1988). Comparison of chlorophyll far-red fluorescence excitation spectra with photosynthetic oxygen action spectra for photosystem II in algae. Mar Ecol. Prog. Ser. 44: 297302

Nielsen, T G., Kiorboe, T., Bjornstn, P. K. (1990). Effects of a Chrysochromulina polylepis subsurface bloom on the plankton community. Mar Ecol. Prog. Ser. 62: 21-35

Pennington, F., Guillard, R. R. L., Liaaen-Jensen, S. (1988). Carotenoid distribution patterns in Bacillariophyceae (Diatoms). Biochem. Syst. Ecol. 16: 589-592

Platt, T., Gallegos, C. L., Harrison, W. G. (1980). Photo-inhibition of photosynthesis in natural assemblages of marine phytoplankton. J. mar Res. 38: 687-701

Richardson, K., Beardall, J., Raven, J. A. (1983). Adaptation of unicellular algae to irradiance: an analysis of strategies. New Phytol. 93: 157-191

Riley, J. P., Wilson, T. R. S. (1967). The pigments of some marine phytoplankton species. J. mar. biol. Ass. U.K. 47: 351-362

Sakshaug, E., Andresen, K. (1986). Effect of light regime upon growth rate and chemical composition of a clone of Skeletonema costatum from the Trondheimsfjord, Norway. J. Plankton Res. 8: 619-637

Sakshaug, E., Andresen, K., Kiefer, D. A. (1989). A steady state description of growth and light absorption in the

This article was presented by $H$. R. Skjoldal, Bergen, Norway marine diatom Skeletonema costatum. Limnol. Oceanogr 34: 198-205

Sakshaug, E., Johnsen, G., Andresen, K., Vernet, M. (1991). Modeling of light-dependent algal photosynthesis and growth: experiments with the Barents Sea diatoms Thalassiosira nordenskioeldii and Chaetoceros furcellatus. Deep Sea Res. 38: 415-430

Skjoldal, H. R., Dundas, I. (eds). (1991). The Chrysochromulina polylepis bloom in the Skagerrak and the Kattegat in May-June 1988: environmental conditions, possible causes, and effects. Coop. Res. Rep. Int. Counc. Explor. Sea (ICES) Workshop. No. $175.59 \mathrm{pp}$

Smith, R. C., Baker, K. S. (1981). Optical properties of the clearest natural waters $(200-800 \mathrm{~nm})$. Appl. Optics 20: $177-184$

Vernet, M., Neori, A., Haxo, F. T (1989). Spectral properties and photosynthetic action in red-tide populations of Prorocentrum micans and Gonyaulax polyedra. Mar Biol. 103: $365-371$

Wright, S. W., Jeffrey, S. W. (1987). Fucoxanthin pigment markers of marine phytoplankton analysed by HPLC and HPTLC. Mar. Ecol. Prog. Ser 38: 259-266

Wright, S. W., Shearer, J. D. (1984). Rapid extraction and highperformance liquid chromatography of chlorophylls and carotenoids from marine phytoplankton. J. Chromatogr 294: 281-295

Manuscript first received: May 14, 1991

Revised version accepted: April 21, 1992 